\title{
Control of anthracnose in banana with cassava starch film associated or not with essential oils
}

\author{
Maria Gilmara de Oliveira Soares ${ }^{1} \oplus$, Eduardo Alves ${ }^{1} \oplus$, Aurivan Soares de Freitas ${ }^{2}(\mathbb{0}$, \\ Cláudia Alves de Almeida ${ }^{3}$, Sarah da Silva Costa ${ }^{1}[0$

\footnotetext{
1 Universidade Federal de Lavras, Lavras, MG, Brasil. E-mail: gilmaraagronomia@gmail.com; ealves@dfp.ufla.br; sarahscguimaraes@yahoo.com.br

2 Universidade Vale do Rio Verde, Três Corações, MG, Brasil. E-mail: aurivan.soares@hotmail.com

${ }^{3}$ Universidade de São Paulo, Escola Superior de Agricultura Luiz de Queiroz, Piracicaba, SP, Brasil. E-mail: almeidaclaudia78@yahoo.com.br
}

ABSTRACT: The objective of this work was to evaluate the in vitro and in vivo potential of cassava starch film associated or not with essential oils in the control of Colletotrichum musae of banana. Were tested clove oils (Eugenia caryophyllata), thyme (Thymus vulgaris), lemongrass (Cymbopogon citratus), cinnamon (Cinnamomum zeylanicum) and oregano (Origanum vulgare) at $0.1 \%$ associated or not with film 2 and $3 \%$. Mycelial growth and conidial germination in vitro and anthracnose in vivo were evaluated. In the curative and preventive controls, the fruits were inoculated with conidia before and after coating, respectively. The major components of essential oils were: eugenol, $\beta$-caryophyllene and a-humulene in clove; thymol, $\rho$-cymene, carvacrol and a-pinene in thyme; geranial and neral in lemongrass; trans-Cinnamaldehyde and eugenol in cinnamon; carvacrol, $\gamma$-Terpinene and linalool in oregano. In vitro, total inhibition of mycelial growth and germination of conidia with oregano oil was observed. The films in the concentrations of 2 and $3 \%$ isolated and combined with oils of lemon grass and thyme, in addition to these isolated oils, provided a reduction in the size of anthracnose lesions.

\section{Controle de antracnose em banana com película de fécula de mandioca associada ou não com óleos essenciais}

RESUMO: Objetivou-se com este trabalho avaliar o potencial in vitro e in vivo de película de fécula de mandioca associada ou não a óleos essenciais no controle de Colletotrichum musae da banana. Foram testados óleos de cravo-da-índia (Eugenia caryophyllata), tomilho (Thymus vulgaris), capim-limão (Cymbopogon citratus), canela (Cinnamomum zeylanicum) e orégano (Origanum vulgare) a 0,1\% associados ou não com película 2 e $3 \%$. Avaliou-se o crescimento micelial e a germinação de conídios in vitro e a antracnose in vivo. Nos controles curativo e preventivo, os frutos foram inoculados com conídios antes e depois do revestimento, respectivamente. Os principais componentes majoritários dos óleos essenciais foram: eugenol, $\beta$-cariofileno e a-humuleno em cravo-da-índia; timol, $\rho$-cimeno, carvacrol e a-pineno em tomilho; geranial e neral em capimlimão; transcinamaldeído e eugenol em canela; carvacrol, y-terpineno e linalol em orégano. In vitro, foi observada inibição total do crescimento micelial e germinação de conídios com óleo de orégano. As películas nas concentrações de 2 e $3 \%$ isoladas e combinadas com óleos de capim-limão e tomilho, além desses óleos isolados, proporcionaram redução no tamanho das lesões de antracnose.

Palavras-chave: Colletotrichum musae; doença; Musa spp.; pós-colheita 


\section{Introduction}

Banana plant (Musa spp.) is a fruit tree widely cultivated in tropical and subtropical regions (FAO, 2019). Besides being one of the most valuable agricultural products in the world, banana fruit is a nutritious, high-energy food source and is an integral part of many diets (Hapsari \& Lestari, 2016). Several fungal diseases can occur in banana during the postharvest phase, including anthracnose, whose causative agent is fungus Colletotrichum musae (Fernandes et al., 2019). The fungus infects green fruits in the field and remains quiescent until maturation. Symptoms manifest as dark black or brown depressed lesions that coalesce with time, forming large necrotic areas which make fruit undesirable for commerce and consumption (Maqbool et al., 2010a).

Disease control basically involves application of fungicides (Khan et al., 2001). However, misused chemicals result in greater risks to the applicator and the environment as well as in selection of fungicide-resistant populations, increases production cost and reduces producer profits (Bastos \& Albuquerque, 2004).

In an attempt to reduce post-harvest losses, fruit treatment with alternative products less toxic to humans and the environment, such as biodegradable cassava starchbased films and essential oils has brought promising results (Botelho et al., 2016; Castro et al., 2017; Sarkhosh et al., 2017; Vilaplana et al., 2018).

Cassava starch is a product extracted from cassava (Manihot esculenta) root in the form of a white, odorless, and tasteless powder. It is used as ingredient in a range of products in various industrial sectors and is also able to form edible films applied in post-harvest fruit preservation (Oriani et al., 2014; Woggum et al., 2014).

Essential oils are lipophilic, low-molecular-weight volatile compounds extracted from various parts of medicinal plants, with characteristic smell and flavor. Application of cassava starch film and essential oils demonstrated promising effects on anthracnose control in fruits such as guava (Rozwalka et al., 2008), mango (Serpa et al., 2014), strawberry (Lorenzetti et al., 2011), papaya (Carnelossi et al., 2009; Bosquez-Molina et al., 2010; Oliveira et al., 2016), and organic banana (Vilaplana et al., 2018). Thus, knowing the action of essential oils associated with cassava starch film can contribute to the development of more promising control strategies for reducing production costs, stimulating consumption of more appealing fruits, and increasing shelf life. This study investigated the potential in vitro and in vivo of cassava starch film associated or not associated with essential oils in the control of $C$. musae in banana fruit.

\section{Materials and Methods}

Fruits, essential oils, cassava starch, and fungicide

Fruits were obtained in a plantation Banana (Musa sp. 'Prata-Anã $A A B$ ') at Vale dos Ventos farmstead, Lavras, state of Minas Gerais. There was no management measure at the site, which allowed studying disease behavior under natural conditions.

Essential oils of clove (Eugenia caryophyllata), thyme (Thymus vulgaris), lemongrass (Cymbopogon citratus), cinnamon (Cinnamomum zeylanicum), and oregano (Origanum vulgare) were purchased from the Quinari company. Cassava starch (Pachá) and fungicide Tecto ${ }^{\circ} \mathrm{SC}$ Syngenta were purchased in local commerce.

\section{Fungal culture and identification}

C. musae was isolated from symptomatic banana fruits. Monosporic culture was prepared by adding $10 \mathrm{~mL}$ of sterile water to the colony plate. A $10 \mu \mathrm{L}$ aliquot was extracted and deposited in $9 \mathrm{~cm}$ diameter petri dishes containing water agar medium (20 g agar per $\mathrm{L}$ of distilled water) then spread with a Drigalski spatula. Dishes were incubated at $25^{\circ} \mathrm{C}$ and $12 \mathrm{~h}$ photoperiod for six days. Then, a germinated conidium was transferred to Petri dishes containing malt agar $(20 \mathrm{~g}$ malt extract and $20 \mathrm{~g}$ agar per $\mathrm{L}$ of distilled water). The monosporic isolate was preserved in a microtube and stored at $10^{\circ} \mathrm{C}$ in the dark and cryopreserved at $-80^{\circ} \mathrm{C}$ in the Lavras Mycological Collection (CML), Laboratory of Systematics and Ecology of Fungi, Department of Phytopathology, Federal University of Lavras (UFLA) with access code CML 3248. The isolate was identified by morphological characters measuring 13-14 $\mu \mathrm{m}$ in length and 4.5-5.4 $\mu \mathrm{m}$ in width, typical of $C$. musae (Weir et al., 2012) and by molecular phylogeny using fragments of genes glyceraldehyde 3-phosphate dehydrogenase (GAPDH) and partial Actin (ACT). The isolate sequences generated in this study were placed in the GenBank, under accession codes KX417772 and KX417773 for GAPDH and ACT gene regions, respectively.

\section{Chemical composition of essential oils}

Chemical analyses were performed by gas chromatography coupled to mass spectrometry (GC-MS). The equipment was operated under the following experimental conditions: fused silica capillary column $(30 \times 0.25 \mathrm{~mm} \times 0.25 \mu \mathrm{m})$; helium gas flow rate of $1.18 \mathrm{~mL} \mathrm{~min}^{-1}$; injector and detector operating at temperatures 200 and $240^{\circ} \mathrm{C}$, respectively. Column temperature was $60{ }^{\circ} \mathrm{C}$, with a heating ramp of $3.0^{\circ} \mathrm{C} \mathrm{min}^{-1}$ until reaching $240{ }^{\circ} \mathrm{C}$ and $10{ }^{\circ} \mathrm{C} \mathrm{min}-1$ until reaching $300{ }^{\circ} \mathrm{C}$, remaining for 7 min with a cut-off time of $3.0 \mathrm{~min}$. Oil samples were diluted in hexane at $1 \% \mathrm{v} / \mathrm{v}$ and injected into the chromatograph with an injection volume of $1.0 \mu \mathrm{L}$ in split mode with 1:100 ratio. The peaks obtained were compared with the Wiley 8 and FFNSC 1.2 libraries database, and the retention indices of compounds relating to co-injection of n-alkane series were calculated by the Van Den Dool \& Kratz method (1963).

Compounds were quantified using flame ionization detector (FID) equipped with an RTX capillary column $(30 \mathrm{~m}$ $\times 0.25 \mathrm{~mm} \times 0.25 \mu \mathrm{m}$ ). Helium was used as carrier gas at 1.18 $\mathrm{mL} \mathrm{min}^{-1}$ flow rate, and injector and detector temperatures were maintained at 220 and $240{ }^{\circ} \mathrm{C}$, respectively. Column conditions and amount of injection were as described above. Results were obtained by normalizing peak areas (\%). 


\section{Treatments and experimental design}

Antifungal activity in vivo and in vitro of $C$. musae was evaluated in 20 treatments consisting of control with only distilled water; negative control with $0.7 \%$ Tween 20 dispersant; positive control with $0.65 \mathrm{~mL} \mathrm{~L}^{-1}$ of Tecto ${ }^{\circ} \mathrm{SC}$ fungicide; cassava starch film at $2 \%$; cassava starch film at $3 \%$; clove essential oil $(0.1 \%)$; thyme essential oil $(0.1 \%)$; lemongrass essential oil $(0.1 \%)$; cinnamon essential oil $(0.1 \%)$; oregano essential oil $(0.1 \%)$; cassava starch film at $2 \%$ associated with clove essential oil; cassava starch film at $3 \%$ associated with clove essential oil; cassava starch film at $2 \%$ associated with thyme oil; cassava starch film at 3\% associated with thyme oil; cassava starch film at $2 \%$ associated with lemongrass essential oil; cassava starch film at 3\% associated with lemongrass essential oil; cassava starch film at $2 \%$ associated with cinnamon essential oil; cassava starch film at $3 \%$ associated with cinnamon essential oil; $2 \%$ cassava starch film associated with oregano essential oil; and cassava starch film at $3 \%$ associated with oregano essential oil.

The experiments were conducted in a completely randomized design with four replicates per treatment. Sampling unit in experiments in vitro was a Petri dish while the experiment in vivo used a banana fruit.

Antifungal activity of essential oils and cassava starch in mycelial growth and percentage of conidial germination of C. musae in vitro

In the evaluation mycelial growth, treatments containing or not a film with essential oil, the cassava starch was autoclaved and prepared in concentrations of 2 and $3 \%$ (weight/volume), being heated in a microwave to $90 \circ \mathrm{C}$ and stirred periodically for 10 seconds, to obtain films without granules. In the plates with already solidified malt medium, containing or not essential oils, depending on the treatment, $1 \mathrm{~mL}$ of films 2 and $3 \%$ were added on the surface of the medium and spread with the aid of the Drigalsky loop. For treatments containing only essential oils, $5 \mathrm{~mL}$ solutions containing distilled water, $0.7 \%$ Tween 20 and $5 \mu \mathrm{L}$ of each oil were prepared. From these solutions, $1 \mathrm{~mL}$ was removed and added to $9 \mathrm{~mL}$ of the melting medium cooled to $45{ }^{\circ} \mathrm{C}$ and poured into plates.

After solidification of the medium, mycelium discs of $5 \mathrm{~mm}$ in diameter were transferred to the center of the plates, then they were sealed with parafilm and incubated at $25{ }^{\circ} \mathrm{C}$ and a photoperiod of $12 \mathrm{~h}$. Mycelial growth was evaluated daily for eight days by measuring colony diameter in two opposite directions using a digital caliper. The mycelial growth rate index (MGRI) was calculated using the Equation 1 proposed by Maguire (1962).

$$
\text { MGRI }=\frac{\mathrm{S}(\mathrm{D}-\mathrm{Da})}{\mathrm{N}}
$$

where: MGRI - mycelial growth rate index; S - summation; D current mean diameter; $\mathrm{Da}$ - mean diameter of the previous day; $\mathrm{N}$ - number of days after inoculation.
Germination of conidia was performed by microscopic analysis of the germinated conidia in agar-water culture medium poured into $9 \mathrm{~cm}$ diameter Petri dishes prepared as mentioned in mycelial growth. After solidification of the culture medium in Petri dishes, $100 \mu \mathrm{L}$ of a $2 \times 10^{6}$ conidia $\mathrm{mL}^{-1}$ suspension were added and spread with a Drigalski spatula. Petri dishes were then incubated at $25{ }^{\circ} \mathrm{C}$, with 12 $\mathrm{h}$ photoperiod. Conidial germination was then stopped with two drops of lactoglycerol cotton blue. Plates were divided into four quadrants with 100 conidia each, totaling 400 conidia per treatment. Conidia with germ tubes longer or equal to conidium diameter were considered germinated.

In vivo activity of essential oils and cassava starch in anthracnose lesions

Activity of essential oils and cassava starch film was evaluated by immersion of fruits in suspension containing treatments before and after inoculation, characterizing preventive and curative control, respectively.

Cassava starch films at concentrations of 2 and $3 \%$ were prepared by diluting 16 and $24 \mathrm{~g}$ cassava starch in $800 \mathrm{~mL}$ distilled water, respectively. Films were then heated in microwave up to $90{ }^{\circ} \mathrm{C}$ and shaken every 10 seconds to obtain gels without granules. The essential oils used in the $0.1 \%$ concentration were diluted in $0.7 \%$ Tween 20 .

After cooling gels in the combined treatments, the essential oils were diluted in Tween 20, added to films at 2 and 3\% with automatic pipette and shaken with glass rod. Treatments with only essential oils received $800 \mu \mathrm{L}$ of each oil. Fruits were then immersed three times in the solutions for one minute, at 3 min intervals (Oliveira et al., 2016).

In the preventive control, fruits were initially treated with cassava starch films at 2 and 3\%, whether or not incorporated in essential oils, dried for $12 \mathrm{~h}$, and then submitted to inoculation. In the curative control, fruits were inoculated and later submitted to the treatments with cassava starch films at 2 and $3 \%$, whether or not incorporated in essential oils.

Inoculation was performed at four different points in the middle part of fruits, previously pierced with five holes, using multi-needles (Soares et al., 2017). For this purpose, $20 \mu \mathrm{L}$ of the $2 \times 10^{6}$ conidia $\mathrm{mL}^{-1}$ suspension were deposited at each point with automatic pipette. Then fruits were covered with plastic bags, forming a humid chamber at $25{ }^{\circ} \mathrm{C}$ and $90 \%$ humidity during $48 \mathrm{~h}$ of wetting. After removal of plastic bags, fruits remained on the bench for $12 \mathrm{~h}$ drying at $26{ }^{\circ} \mathrm{C}$ and $60 \%$ relative humidity. Later, fruits were put on plastic supports and placed under the laboratory bench.

Evaluations were performed daily by measuring lesions in two perpendicular directions using digital caliper. Then, the mean injured area was calculated in $\mathrm{cm}^{2}$ at the inoculated points, using the formula for calculating circle area: $A=\pi r^{2}$, where: $A=$ injured area; $\pi=$ constant (3.1416) and $r=$ mean radius of the lesion.

\section{Statistical analysis}

Normality of data were confirmed using the Shapiro-Wilk test (Shapiro \& Wilk 1965). Data were submitted to analysis 
of variance. Significant variables in the $F$ test $(p \leq 0.05)$ were compared by the Scott-Knott test at 5\% probability. Analyses were performed using the Sisvar software (Ferreira, 2011).

\section{Results}

\section{Chemical composition of essential oils}

Table 1 shows results of GC-MS analyses of the five essential oils. The main chemical components of clove oil were eugenol (83.73\%), $\beta$-caryophyllene (13.40\%), and $\alpha$-humulene (1.51\%). The most abundant compounds identified in cinnamon oil were trans-cinnamaldehyde (90.3\%) and eugenol (8.45\%). Geranial $(54.50 \%)$ and neral $(36.87 \%)$ were the main constituents of lemongrass oil. Carvacrol (77.34\%) followed by $\gamma$-terpinene (12.36\%) and linalool (6.48\%) were the major components of oregano oil, followed by $\rho$-cymene $(24.04 \%)$, carvacrol (21.97\%) and $\alpha$-pinene (5.87\%). Chromatogram for thyme oil showed 22 peaks. Thymol $(26.84 \%)$ presented higher levels, followed by $\rho$-cymene (24.04\%), carvacrol (21.97\%), and $\alpha$-pinene (5.87\%).

Antifungal activity of essential oils and cassava starch in vitro in inhibition of mycelial growth and conidial germination of Colletotrichum musae

Treatments with oregano and cinnamon oils isolated or combined with 2 and $3 \%$ cassava starch film, likewise Tecto ${ }^{\circ} \mathrm{SC}$ fungicide, had a greater effect on reduction of mycelial growth

Table 1. Chemical composition (relative percentage) of five different essential oils.

\begin{tabular}{|c|c|c|c|c|c|c|}
\hline Compounds & ${ }^{2} \mathbf{R I}$ & E. caryophyllata & C. zeylanicum & C. citratus & O. vulgare & T. vulgaris \\
\hline Eugenol & 1289 & 83.73 & 8.45 & - & - & - \\
\hline$\beta$-Caryophyllene & 1378 & 13.40 & - & - & - & - \\
\hline$\alpha$-Humulene & 1383 & 1.51 & - & - & - & - \\
\hline$\alpha$-Copaene & 1293 & 0.17 & - & - & - & - \\
\hline trans-Cinnamaldehyde & 1201 & - & 90.3 & - & - & - \\
\hline Sabinene & 1383 & - & 1.25 & - & - & - \\
\hline Neral & 1193 & - & - & 36.87 & - & - \\
\hline Geranyl acetate & 1288 & - & - & 1.68 & - & - \\
\hline Caryophyllene oxide & 1392 & - & - & 1.26 & - & - \\
\hline Citronellyl formate & 1190 & - & - & 1.13 & - & - \\
\hline Bergamal & 1038 & - & - & 1.12 & - & - \\
\hline Citronellyl isobutyrate & 1204 & - & - & 0.25 & - & - \\
\hline Germacrene D & 1378 & - & - & 0.10 & - & - \\
\hline Carvacrol & 1205 & - & - & - & 77.34 & 21.97 \\
\hline$\gamma$-Terpinene & 1010 & - & - & - & 12.36 & 0.47 \\
\hline Linalool & 1010 & - & - & - & 6.48 & 2.55 \\
\hline Myrcene & 926 & - & - & - & 1.68 & - \\
\hline Thymol & 1089 & - & - & - & 1.67 & - \\
\hline$\rho$-Cymene & 1000 & - & - & - & 0.27 & 24.04 \\
\hline Terpinolene & 998 & - & - & - & 0.20 & - \\
\hline Thymol & 1279 & - & - & - & - & 26.84 \\
\hline$\alpha$-Pinene & 903 & - & - & - & - & 5.87 \\
\hline$\delta$-3-Carene & 907 & - & - & - & - & 3.54 \\
\hline Terpin-4-ol & 1108 & - & - & - & - & 3.37 \\
\hline Camphor & 980 & - & - & - & - & 0.53 \\
\hline Terpinolene & 1010 & - & - & - & - & 0.50 \\
\hline Myrcene & 987 & - & - & - & - & 0.49 \\
\hline Sabinene & 987 & - & - & - & - & 0.38 \\
\hline$\beta$-Ocimene & 994 & - & - & - & - & 0.30 \\
\hline$\alpha$-Phellandrene & 989 & - & - & - & - & 0.26 \\
\hline$\alpha$-Selinene & 1280 & - & - & - & - & 0.12 \\
\hline Total & & 100 & 100 & 97.75 & 100 & 100 \\
\hline
\end{tabular}

${ }^{2} \mathrm{RI}$ retention indices relative to the $\mathrm{nC} 8-\mathrm{nC} 25 \mathrm{n}$-alkanes series on DB-5 column. 
and conidial germination. Isolated clove oil showed secondary antifungal activity, inhibiting mycelial growth and germination in $5.58 \mathrm{~mm}$ day $^{-1}$ and $22.5 \%$, respectively (Table 2 ).

Cassava starch films 2 and 3\% combined with essential oil of thyme, as well as isolated essential oils of thyme and lemongrass had intermediate effect on mycelial growth with averages 7.10, 6.96, 6.38, and $6.62 \mathrm{~mm}^{\text {day }}{ }^{-1}$, respectively. Intermediate effect in conidial germination was verified with the Intermediate effect in conidial germination was verified with the cinnamon essential oil (OECI) isolated, presenting germination of $22.50 \%$ (Table 2 ).

Cassava starch films 2 and $3 \%$ had mycelial growth of 10.56 and $10.20 \mathrm{~mm}$ day $^{-1}$ and conidial germination of 87.00 and $81.87 \%$, respectively (Table 2 ). These results confirm the inefficiency of films, as they did not differ statistically from the control mycelial growth (10.63 $\left.\mathrm{mm} \mathrm{day}^{-1}\right)$ and negative control $\left(10.45 \mathrm{~mm}\right.$ day $\left.^{-1}\right)$, also not differing from the negative control $(87.37 \%)$ in conidial germination.

Evaluation of efficiency of cassava starch film and essential oils in vivo in preventive and curative control of banana anthracnose

Preventively, treatments providing the greatest reduction in lesion sizes were lemongrass and thyme oils either isolated or combined with cassava starch films 2 and 3\%, as well as isolated cassava starch films $2 \%$ and $3 \%$, thyme oil associated with $2 \%$ cassava starch film and fungicide Tecto ${ }^{\circ} \mathrm{SC}$ (Figure 1A). Similarly, these same treatments presented the best results in the curative control, although with addition of clove oil isolated or associated with $3 \%$ cassava starch film (Figure $1 \mathrm{~B}$ ). In both types of control, preventive and curative, fruits treated with these products showed low- developed lesions.

Essential oils of cinnamon and oregano were not efficient in the control of anthracnose when not combined with cassava starch films at 2 and 3\%. Lesions were larger, with sizes of 10.35 $\mathrm{cm}^{2}$ and $10.68 \mathrm{~cm}^{2}$ in the curative experiment (Figure $1 \mathrm{~A}$ ) and 7.88 and $9.94 \mathrm{~cm}^{2}$ in the preventive experiment (Figure 1B).

Tecto ${ }^{\circ} \mathrm{SC}$ fungicide presented low efficiency in the curative control with lesion size $9.89 \mathrm{~cm}^{2}$, not differing from control and Tween 20 dispersant, which presented lesions with sizes 11.04 and $10.54 \mathrm{~cm}^{2}$, respectively (Figure $1 \mathrm{~A}$ ).

Cassava starch films 2 and 3\% either associated or not associated with essential oils were efficient in anthracnose control, being much more expressive at a concentration of $3 \%$ with average lesion size 1.69 and $1.35 \mathrm{~cm}^{2}$ in preventive and curative experiments, respectively (Figure $1 \mathrm{~A}$ and $1 \mathrm{~B}$ ).

\section{Discussion}

In the present study, 11 compounds were identified in lemongrass oil, representing $97.75 \%$ of total constituents. Total constituents in clove, cinnamon, oregano, and thyme oils represented $100 \%$ of total area. Similar to our results, Scherer et al. (2009) found in clove oil the main components eugenol (83.75\%) and $\beta$-caryophyllene (10.98\%) followed by $\alpha$-humulene (1.26\%). Beraldo et al. (2013), Oliveira et al. (2009) and Snoussi et al. (2008) identified eugenol in carnation flower buds in values $77.58,88.38$, and $88.58 \%$, respectively.

Table 2. Effect of different in vitro treatments on the mycelial growth rate index (MGRI) and on the percentage of germination of Colletotrichum musae conidia.

\begin{tabular}{|c|c|c|c|}
\hline Treatments & *Mean of MGRI (mm day $\left.{ }^{-1}\right)$ & Treatments & *Germination (\%) \\
\hline Control & $10.63 a$ & Control & $98.12 \mathrm{a}$ \\
\hline CSF $2 \%$ & $10.56 \mathrm{a}$ & Tween20 dispersant & $87.37 b$ \\
\hline Tween20 dispersant & 10.45 a & CSF $2 \%$ & $87.00 \mathrm{~b}$ \\
\hline CSF $3 \%$ & $10.20 a$ & OELE & $84.37 b$ \\
\hline CSF $2 \%+$ OELE & $10.11 \mathrm{a}$ & OETH & $83.75 b$ \\
\hline CSF $3 \%+$ OELE & $8.53 b$ & CSF $3 \%$ & $81.87 b$ \\
\hline CSF $2 \%+$ OETH & $7.10 \mathrm{c}$ & CSF $2 \%+$ OELE & $70.50 \mathrm{c}$ \\
\hline CSF $3 \%+\mathrm{OETH}$ & $6.96 \mathrm{c}$ & CSF $2 \%+$ OETH & $62.37 \mathrm{~d}$ \\
\hline OELE & $6.62 \mathrm{~d}$ & CSF $3 \%+$ OETH & $55.87 \mathrm{e}$ \\
\hline OETH & $6.38 \mathrm{~d}$ & CSF $3 \%+$ OELE & $53.37 \mathrm{e}$ \\
\hline OECL & $5.58 \mathrm{e}$ & OECL & $22.50 \mathrm{f}$ \\
\hline $\mathrm{OECl}$ & $2.28 \mathrm{f}$ & $\mathrm{OECl}$ & $1.75 \mathrm{~g}$ \\
\hline CSF $2 \%+O E C L$ & $0.14 \mathrm{~g}$ & $\mathrm{CSF} 3 \%+\mathrm{OECl}$ & $1.62 \mathrm{~g}$ \\
\hline CSF $3 \%+O E C L$ & $0.08 \mathrm{~g}$ & $\mathrm{CSF} 2 \%+\mathrm{OECl}$ & $1.50 \mathrm{~g}$ \\
\hline $\mathrm{CSF} 2 \%+\mathrm{OECl}$ & $0.03 \mathrm{~g}$ & CSF $3 \%+O E C L$ & $1.37 \mathrm{~g}$ \\
\hline $\mathrm{CSF} 3 \%+\mathrm{OECl}$ & $0.02 \mathrm{~g}$ & CSF $2 \%+O E C L$ & $1.55 \mathrm{~g}$ \\
\hline OEOR & $0.00 \mathrm{~g}$ & CSF $2 \%+$ OEOR & $1.00 \mathrm{~g}$ \\
\hline CSF $2 \%+$ OEOR & $0.00 \mathrm{~g}$ & CSF $3 \%+O E O R$ & $0.87 \mathrm{~g}$ \\
\hline CSF $3 \%+$ OEOR & $0.00 \mathrm{~g}$ & OEOR & $0.00 \mathrm{~g}$ \\
\hline Tecto ${ }^{\circ}$ SC fungicide & $0.00 \mathrm{~g}$ & Tecto ${ }^{\circledR}$ SC fungicide & $0.00 \mathrm{~g}$ \\
\hline \multicolumn{4}{|c|}{ 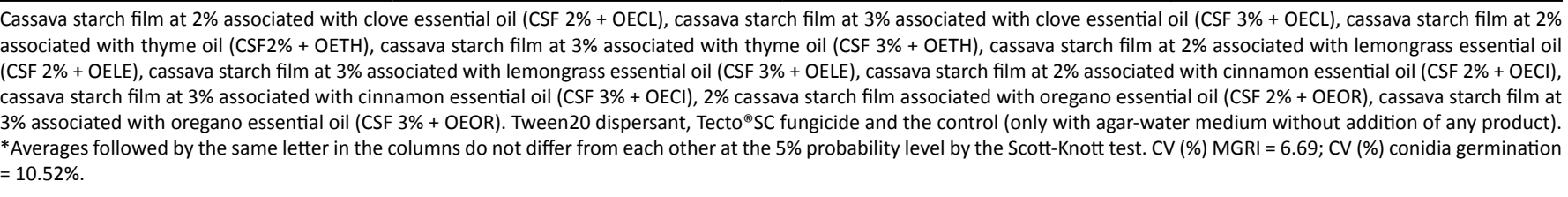 } \\
\hline
\end{tabular}



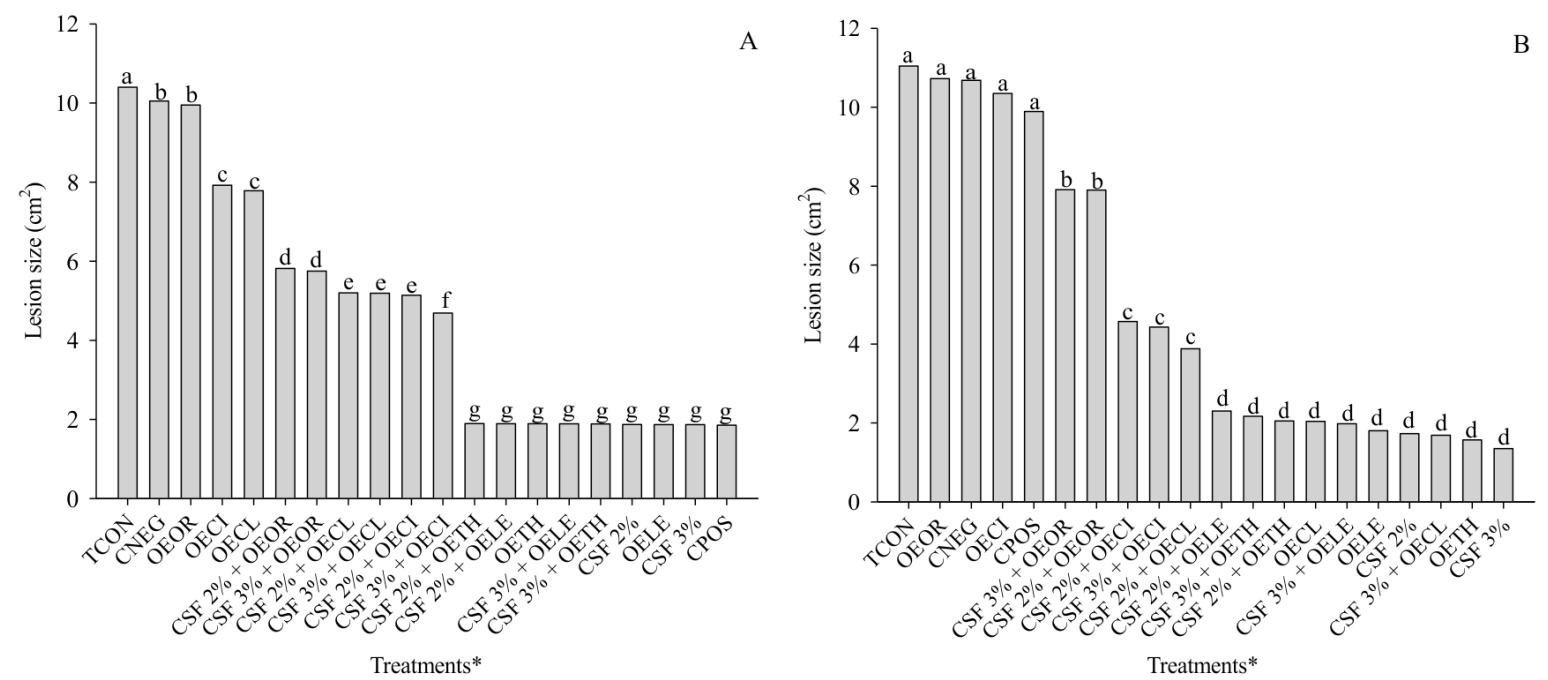

TCON: control treatment with only distilled water; CNEG: negative control with Tween 20 dispersant; CPOS: positive control with Tecto ${ }^{\circ} \mathrm{SC}$ fungicide; cassava starch film at $2 \%$ (CSF $2 \%$ ); cassava starch film at 3\% (CSF 3\%), clove essential oil (OECL), thyme essential oil (OETH), lemongrass essential oil (OELE), cinnamon essential oil (OECI), oregano essential oil (OEOR), cassava starch film at $2 \%$ associated with clove essential oil (CSF $2 \%+\mathrm{OECL}$ ), cassava starch film at $3 \%$ associated with clove essential oil (CSF $3 \%+\mathrm{OECL}$ ), cassava starch film at $2 \%$ associated with thyme oil (CSF $2 \%+\mathrm{OETH}$ ), cassava starch film at $3 \%$ associated with thyme oil (CSF $3 \%+\mathrm{OETH}$ ), cassava starch film at $2 \%$ associated with lemongrass essential oil (CSF $2 \%+$ OELE), cassava starch film at $3 \%$ associated with lemongrass essential oil (CSF $3 \%+$ OELE), cassava starch film at $2 \%$ associated with cinnamon essential oil (CSF $2 \%+$ OECI), cassava starch film at $3 \%$ associated with cinnamon essential oil (CSF $3 \%+\mathrm{OECI}$ ), $2 \%$ cassava starch film associated with oregano essential oil (CSF $2 \%+$ OEOR), cassava starch film at $3 \%$ associated with oregano essential oil (CSF $3 \%+$ OEOR). * Treatments followed by the same letter do not differ at the $5 \%$ probability level by the Scott-Knott test. CV(\%) preventive $=10.28, \mathrm{CV}(\%)$ curative $=6.06$.

Figure 1. Size of the anthracnose lesion in banana fruits treated preventive $(A)$ and curative $(B)$ in function on the treatments.

Andrade et al. (2012) found the presence of 14 constituents in cinnamon oil, with trans-cinnamaldehyde $(77.72 \%)$ as the main component, as well as eugenol (8.5\%) found by Sarkhosh et al. (2017). In lemongrass oil, Oliveira et al. (2011) identified geranial and neral components with 30.91 and $42.92 \%$, respectively. Silva et al. (2010) identified carvacrol as the main component in oregano oil with contents ranging from 61.66 to $93.42 \%$, which are similar to the values obtained in this study. According to Oliveira et al. (2011), phenols, such as carvacrol and thymol, can reach total chemical composition of thyme oil at 80.2 to $98.0 \%$ and promote disease control, especially in post-harvest period.

Results in vitro in this study suggest that the combination of clove, cinnamon, and oregano essential oil with cassava starch films at 2 and $3 \%$, as well as with oregano oil only, had the greatest effects against anthracnose agent (C. musae) in banana fruits (Table 2). Several authors have reported the efficiency of essential oils of oregano, thyme, and lemongrass in experiments in vitro. Romero et al. (2012) found total inhibition of mycelial growth and germination of Corynespora cassiicola, Fusarium sp., Colletotrichum gloeosporioides and Rhizoctonia solani with oregano oil. These authors attributed the results to high presence of phenolic compounds carvacrol and thymol in oregano oil, as also verified in this study (Table 1), which are able to alter constituent proteins of cell membranes and inhibit cell activities. Vilaplana et al. (2018) found that thyme oil at $500 \mu \mathrm{L} \mathrm{L}^{-1}$ concentration promoted total inhibition of mycelial growth of $C$. musae in banana fruits. According to Simões \& Spitzer (2000), low efficiency of some essential oils can be attributed to volatilization of chemical compounds or instability in the presence of air, heat, light, and moisture. In view of the information, it is possible to emphasize that low efficiency of clove and lemongrass oils is possibly related to variation of environmental conditions and high volatile activity of these chemical compounds, which promoted sensitivity to the pathogen. It should also be considered that some oils may have better effects on germination but not on mycelial growth, as verified in this study.

Cinnamon oil showed antifungal activity on mycelial growth and fungus germination. These results agree with Maqbool et al. (2010b), who verified inhibition of $83.2 \%$ of growth and spore germination of $C$. musae. The authors also attributed these results to high content of cinnamaldehyde, which can react with proteins and nucleic acid and interfere with cellular processes. In view of this information, associated with the fact that trans-cinnamaldehyde and eugenol are present in high levels, it is understandable that antifungal activity is related to the action of these compounds.

Essential oils of lemongrass and thyme used in vivo were considered more efficient in the control of banana anthracnose. It was evidenced in other fruits that these oils are promising sources in post-harvest control of anthracnose. Smaller lesions were observed in papaya fruit treated with lemongrass, eucalyptus, mint, and tarragon oils (Carnelossi et al., 2009). Bosquez-Molina et al. (2010) reported that combination of algaroba gum $10 \%$ and thyme oil $0.1 \%$ resulted in $100 \%$ reduction of anthracnose in papaya fruits. In avocado, thyme oil $1 \%$ in combination with chitosan $1 \%$ and isolated at $0.02 \%$ reduced lesions from anthracnose (Bill et al., 2014; Sarkhosh et al., 2017). Moura et al. (2012) found in passion fruit a reduction in anthracnose severity with lemongrass oil at $0.1 \%$ concentration. Garcia et al. (2008) observed $70 \%$ reduction in development of lesions with application of citral $1.0 \%$ in papaya and banana fruits. These authors attributed the antifungal activity of lemongrass oil to the high presence of citral in its constitution, which was also identified in this study in larger quantities. 

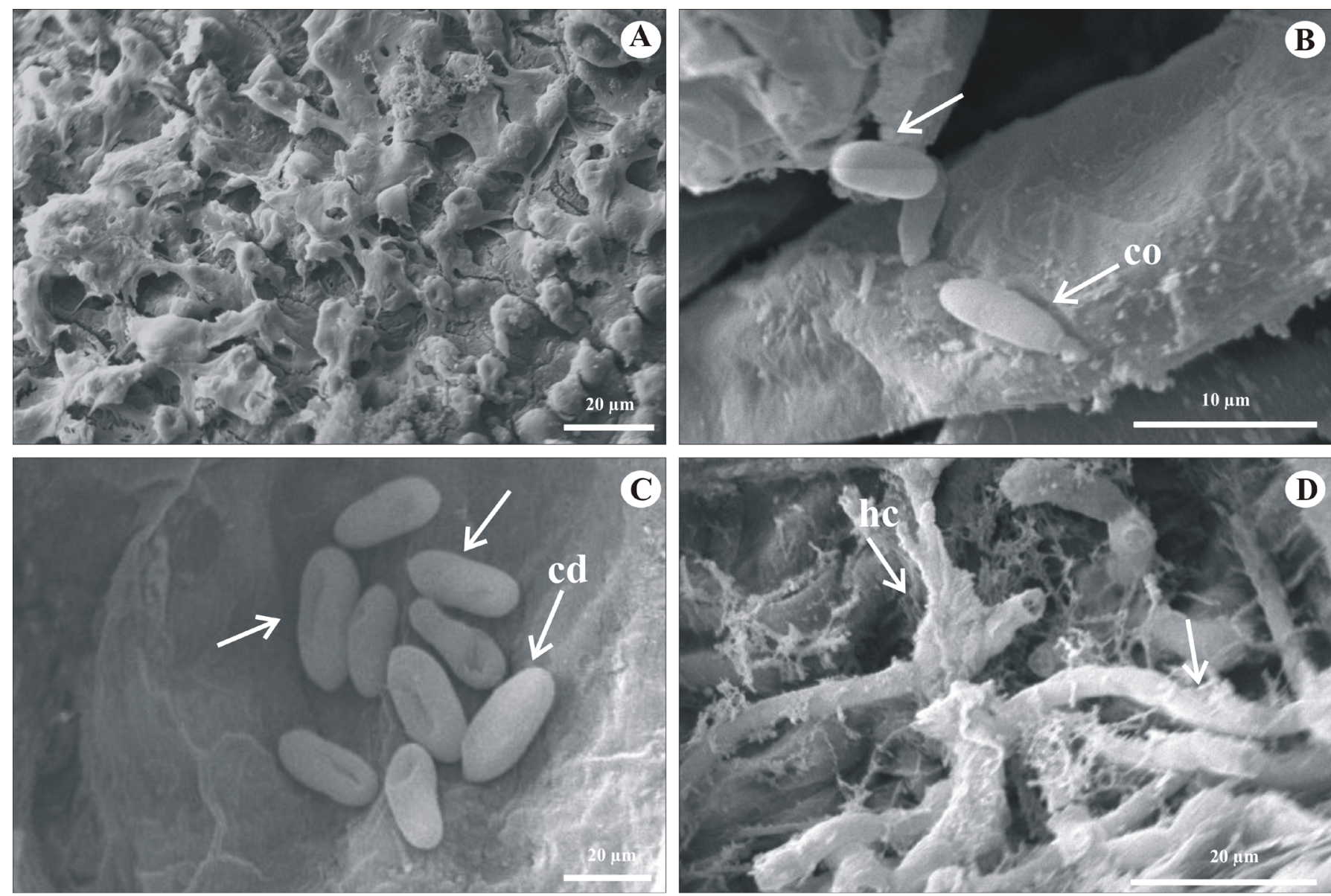

Figure 2. Scanning electromicrographs of the protective layer promoted by cassava starch film $3 \%(A)$, non-germinated and deformed Colletotrichum musae conidia (B, C) and collapsed hyphae (D) from the action of essential oil of lemongrass and thyme. co: conidia, cd: deformed conidia, hc: collapsed hyphae.

The efficiency of films only in analysis in vivo can be attributed to some property in starch composition that acts differently on the fruit, causing an obstacle to pathogen development. Oliveira et al. (2016) observed the positive effect of cassava starch films 2,3 and $4 \%$ on the control of anthracnose in papaya fruit, attributing the efficiency of cassava starch to a protective layer that prevented the pathogen from entering fruit tissues. Images performed by scanning electron microscopy in this study showed a layer on fruit outer surface provided by films which prevented penetration of fungus $C$. musae (Figure 2A). In addition, it was possible to observe direct action of essential oils of thyme and lemongrass on the pathogen which promoted inhibition of conidia germination, leaving them in deformed appearance and causing deformations in the hyphae, thus preventing colonization in fruit tissues (Figure 2B, 2C, and 2D).

Some treatments presented both isolated and combined significant effects, which can be explained by characteristics of essential oils such as volatilization, solubility, and concentration, as well as environmental conditions of humidity, light, and temperature (Guimarães et al., 2008). However, there is great complexity in the mechanism of action of essential oils and cassava starch that is not yet known, and protein denaturation and membrane disintegration may occur during the pathogen infection process (Andrade et al., 2014).

\section{Conclusion}

The application of oregano essential oil in vitro completely inhibits mycelial growth and germination of Colletotrichum musae conidia.

Lemongrass and thyme essential oils and individual cassava starch films at $2 \%$ and $3 \%$, as well as their combination, are effective in reducing and preventing anthracnose lesions in banana fruits and may be indicated as a viable strategy for alternative control of post-harvest anthracnose.

\section{Literature Cited}

Andrade, B.F.M.T.; Barbosa, L.N.; Probst, I.S.; Fernandes Júnior, A. Antimicrobial activity of essential oils, Journal of Essential Oil Research, v.26, n.1, 34-40, 2014. https://doi.org/10.1080/1041 2905.2013.860409.

Andrade, M.A.; Cardoso, M.D.G.; Batista, L.R.; Mallet, A.C.T.; Machado, S.M.F. Essential oils of Cinnamomum zeylanicum, Cymbopogon nardus and Zingiber officinale: composition, antioxidant and antibacterial activities. Revista Ciência Agronômica, v.43, n.2, p.399-408, 2012. https://doi.org/10.1590/ S1806-66902012000200025. 
Bastos, C.N.; Albuquerque, P.S.B. The effect of essential oil of Piper aduncum in controlling Colletotrichum musae on post-harvest bananas. Fitopatologia Brasileira, v.29, n.5, p.555-557, 2004. https://doi.org/10.1590/S0100-41582004000500016.

Beraldo, C.; Daneluzzi, N.S.; Scanavacca, J.; Doyama, J.T.; Júnior, A.F.; Moritz, C.M.F. Efficiency of cinnamon and clove essential oils as sanitizers in the food industry. Pesquisa Agropecuária Tropical, v.43, n.4, p.436-440, 2013. https://doi.org/10.1590/S198340632013000400006.

Bill, M.; Sivakumar, D.; Korsten, L.; Thompson, A.K. The efficacy of combined application of edible coatings and thyme oil in inducing resistance components in avocado (Persea americana Mill.) against anthracnose during post-harvest storage. Crop Protection, v.64, p.159-167, 2014. https://doi.org/10.1016/j. cropro.2014.06.015.

Bosquez-Molina, E.; Jesús, E.R.D.; Bautista-Baños, S.; Verde-Calvo, J.R.; Morales-López, J. Inhibitory effect of essential oils against Colletotrichum gloeosporioides and Rhizopus stolonifer in stored papaya fruit and their possible application in coatings. Postharvest Biology and Technology, v.57, n.2, p.132-137, 2010. https://doi.org/10.1016/j.postharvbio.2010.03.008.

Botelho, L.N.S.; Rocha, D.A.; Braga, M.A.; Silva, A.; Abreu, C.M.P. Quality of guava cv.'Pedro Sato'treated with cassava starch and cinnamon essential oil. Scientia horticulturae, v.209, n.19, p.214220, 2016. https://doi.org/10.1016/j.scienta.2016.06.012.

Carnelossi, P. R.; Schwan-Estrada, K.R.F.; Cruz, M.E.S.; Itako, A.T.; Mesquini, R.M. Essential oils on post-harvest control of Colletotrichum gloeosporioides in papaya fruit. Revista Brasileira de Plantas Medicinais, v.11, n.4, p.399-406, 2009. https://doi. org/10.1590/S1516-05722009000400007.

Castro, M.; Mantuano, M.I.; Coloma, J.L.; Santa Cruz., S. Utilisation of Cassava starch edible films containing salicylic acid on papaya (Carica papaya L.) preservation. Revista Politécnica, v.39, n.1, p.712, 2017. http://scielo.senescyt.gob.ec/scielo.php?script=sci_ arttext\&pid=S1390-01292017000100007\&Ing=en\&nrm=iso. 18 Jan. 2020.

Fernandes, M. B.; Mizobutsi, E. H.; Rodrigues, M. L. M.; Ribeiro, R. C. F.; Mizobutsi, G. P.; Pinho, D. B. Bagging time of 'Prataanã'banana regarding anthracnose control. Revista Brasileira de Fruticultura, v.41, n.1, p.1-8, 2019. https://doi.org/10.1590/010029452019066

Ferreira, D.F. Sisvar: a computer statistical analysis system. Ciência e Agrotecnologia, v. 35, n.6, p.1039-1042, 2011. https://doi. org/10.1590/S1413-70542011000600001

Food and Agriculture Organization of the United Nations - FAO. Faostat. http://faostat.fao.org. 04 Dec 2019.

Garcia, R.; Alves, E.S.; Santos, M.P.; Aquije, G.M.; Fernandes, A.A.R.; Santos, R.B.D.; Fernandes, P. Antimicrobial activity and potential use of monoterpenes as tropical fruits preservatives. Brazilian Journal of Microbiology, v.39, n.1, p.163-168, 2008. https://doi. org/10.1590/S1517-83822008000100032.

Guimarães, L.G.D.L.; Cardoso, M.D.G.; Zacaroni, L.M.; Lima, R.K.D.; Pimentel, F.A.; Morais, A.R.D. Influência da luz e da temperatura sobre a oxidação do óleo essencial de capim-limão (Cymbopogon citratus (DC) Stapf). Química Nova, v.31, n.6, p.1476-1480, 2008. https://doi.org/10.1590/S0100-40422008000600037.
Hapsari, L.; Lestari, D. A. Fruit characteristic and nutrient values of four Indonesian banana cultivars (Musa spp.) at different genomic groups. AGRIVITA Journal of Agricultural Science, v.38, n.3, p.303311, 2016. http://doi.org/10.17503/agrivita.v38i3.696.

Khan, S.H.; Aked, J.; Magan, N. Control of the anthracnose pathogen of banana (Colletotrichum musae) using antioxidants alone and in combination with thiabendazole or imazalil. Plant Pathology, v.50, n.5, p.601-608, 2001. https://doi.org/10.1046/j.13653059.2001.00599.x.

Lorenzetti, E.R.; Monteiro, F.P.; Souza, P.E.; Souza, R.J.; Scalice, H.K.; Diogo, J.R.; Pires, M.S.O. Essential oils bioactivity in strawberry grey mould control. Revista Brasileira de Plantas Medicinais, v.13, n.spe., p.619-627, 2011. https://doi.org/10.1590/S151605722011000500019.

Maguire, J.D. Speed of germination in selection and evaluation for seedling emergence and vigor. Crop Science, v.2, n.2, p.176-177, 1962. https://doi.org/10.2135/ cropsci1962.0011183X000200020033x.

Maqbool, M.; Ali, A.; Alderson, P.G. Effect of cinnamon oil on incidence of anthracnose disease and post-harvest quality of bananas during storage. International Journal of Agriculture and Biology, v.12, n.4, p.516-520, 2010b.

Maqbool, M.; Ali, A.; Alderson., P. A combination of gum arabic and chitosan can control anthracnose caused by Colletotrichum musae and enhance the shelf-life of banana fruit. Journal of Horticultural Science \& Biotechnology, v.85, n.5, p.432-436, 2010a. https://doi.org/10.1080/14620316.2010.11512693.

Moura, G.S.; Schwan-Estrada, K.R.F.; Alves, A.P.F.; Franzener, G.; Stangarlin, J.R. Control of anthracnose in yellow passion fruit by lemon grass (Cymbopogon Citratus) derivatives. Arquivos do Instituto Biológico, v.79, n.3, p.371-379, 2012. https://doi. org/10.1590/S1808-16572012000300007.

Oliveira, B.F.; Cruz, A.F.; Alves, E. Cassava starch coatings for postharvest control of papaya anthracnose. Phytopathologia Mediterranea, v.55, n.2, p.276-284, 2016. https://doi. org/10.14601/Phytopathol_Mediterr-15214.

Oliveira, M. M. M.; Brugnera, D.F.; Cardoso, M.G.; Guimarães, L.G.L.; Piccoli, R.H. Yield, chemical composition and antilisterial activity of essential oils from Cymbopogon species. Revista Brasileira de Plantas Medicinais, v.13, v.1, p.8-16, 2011. https://doi. org/10.1590/S1516-05722011000100002.

Oliveira, R.A.D.; Reis, T.V.; Sacramento, C.K.D.; Duarte, L.P.; Oliveira, F.F.D. Volatile chemical constituents of rich spices in eugenol. Revista Brasileira de Farmacognosia, v.19, n.3, p.771-775, 2009. https://doi.org/10.1590/S0102-695X2009000500020.

Oriani, V.B.; Molina, G.; Chiumarelli, M.; Pastore, G.M.; Hubinger, M.D. Properties of cassava starch-based edible coating containing essential oils. Journal of Food Science, v.79, n.2, E189-E194, 2014. https://doi.org/10.1111/1750-3841.12332.

Romero, A.L.; Romero, R.B.; Silva, E.L.; Diniz, S.D.S.; Oliveira, R.R.; Vida, J.B. Chemical composition and activity of Origanum vulgare essential oil against phytopathogenic fungi. UNOPAR Científica Ciências Biológicas e da Saúde, v.14, n.4, p.231-235, 2012. https://revista.pgsskroton.com/index.php/JHealthSci/article/ view/865. 12 Jan. 2020. 
Rozwalka, L.C.; Lima, M.L.R.Z.C.; Mio, L.L.M.; Nakashima, T. Extracts, decoctions and essential oils of medicinal and aromatic plants in the inhibition of Colletotrichum gloeosporioides and Glomerella cingulata isolates from guava fruits. Ciência Rural, v.38, n.2, p.301-307, 2008. https://doi.org/10.1590/S010384782008000200001.

Sarkhosh, A.; Vargas, A.I.; Schaffer, B.; Palmateer, A.J.; Lopez, P.; Soleymani, A.; Farzaneh, M. Post-harvest management of anthracnose in avocado (Persea americana Mill.) fruit with plantextracted oils. Food Packaging and Shelf Life, v.12, p.16-22, 2017. https://doi.org/10.1016/j.fpsl.2017.02.001.

Scherer, R.; Wagner, R.; Duarte, M.C.T.; Godoy, H.T. Composition and antioxidant and antimicrobial activities of clove, citronella and palmarosa essential oils. Revista Brasileira de Plantas Medicinais, v.11, n.4, p.442-449, 2009. https://doi.org/10.1590/S151605722009000400013.

Serpa, M.F.P.; Castricini, A.; Mitsobuzi, G.P.; Martins, R.N.; Batista, M.F.; Almeida, T.H. Mango conservation using cassava starch prepared with extract of clove and cinnamon. Revista Ceres, v.61, n.6, p.975-982, 2014. https://doi.org/10.1590/0034737X201461060013.

Shapiro, S.S.; Wilk, M.B. An analysis of variance test for normality (complete samples). Biometrika, v.52, n.3/4, p.591-611, 1965. https://doi.org/10.1093/biomet/52.3-4.591.

Silva, J.P.L.; Duarte-Almeida, J.M.; Perez, D.V.; Franco, B.D.G.M. Oregano essential oil: influence of the chemical composition on the inhibitory activity against Salmonella Enteritidis. Food Science and Technology, v.30, n.1, p.136-141, 2010. https://doi. org/10.1590/s0101-20612010000500021.
Simões, C.M.O.; Spitzer, V. Óleos voláteis. In: Simões, C.M.O.; Schenkel, E.P.; Gosmann, G.; Mello, J.C.P.D.; Mentz, L.A.; Petrovick, P.R. (Eds.). Farmacognosia da planta ao medicamento. Porto Alegre: Editora da Universidade Federal do Rio Grande do Sul, 2000. p.387-415.

Snoussi, M.; Hajlaoui, H.; Noumi, E.; Usai, D.; Sechi, L.A.; Zanetti, S.; Bakhrouf, A. In-vitro anti-Vibrio spp. activity and chemical composition of some Tunisian aromatic plants. World Journal of Microbiology and Biotechnology, v.24, n.12, p.3071-3076, 2008. https://doi.org/10.1007/s11274-008-9848-6.

Soares, M.G.O.; Alves, E.; Freitas, A.S. Influence of inoculation and watering in the development of Colletotrichum musae injuries in banana. Agrotrópica, v.29, n.3, p.213-218, 2017. https://doi. org/10.21757/0103-3816.2017v29n3p213-218.

Van Den Dool, H.; Kratz, P.D. A generalization of the retention index system including liner temperature programmed gas-liquid partition chromatography. Journal of Chromatography A, v.11, p.463-471, 1963. https://doi.org/10.1016/S0021-9673(01)80947-X.

Vilaplana, R.; Pazmiño, L.; Valencia-Chamorro, S. Control of anthracnose, caused by Colletotrichum musae, on postharvest organic banana by thyme oil. Post-harvest Biology and Technology, v.138, p.56-63, 2018. https://doi.org/10.1016/j. postharvbio.2017.12.008.

Weir, B.S.; Johnston, P.R.; Damm, U. The Colletotrichum gloeosporioides species complex. Studies in Mycology, v.73, n.1, p.115-180, 2012. https://doi.org/10.3114/sim0011.

Woggum, T.; Sirivongpaisal, P.; Wittaya, T. Propertiesand characteristics of dual-modified rice starch based biodegradable films. International Journal of Biological Macromolecules, v.67, p.490502, 2014. https://doi.org/10.1016/j.ijbiomac.2014.03.029. 